\title{
日本における尿路性器癌死亡の地域差および年代差
}

\author{
1)群馬県立がんセンター泌尿器科（部長：佐藤 仁） \\ 2)群馬大学医学部泌尿器科 (主任：山中英壽教授) \\ 中田 誠司 ${ }^{1)}$ 佐藤 仁 ${ }^{1)}$ 大竹 伸明 ${ }^{2)}$ 山中 英壽 ${ }^{2}$

\section{REGIONAL AND CHRONOLOGICAL DIFFERENCES OF UROGENITAL CANCER DEATHS IN JAPAN} \\ Seiji Nakata ${ }^{1)}$, Jin Sato ${ }^{1)}$, Nobuaki Ohtake ${ }^{2)}$ and Hidetoshi Yamanaka ${ }^{2)}$ \\ ${ }^{1)}$ Department of Urology, Gunma Cancer Center \\ (Chief: J. Sato) \\ ${ }^{2}$ Department of Urology, Gunma University School of Medicine \\ (Director: Prof. H. Yamanaka)
}

(Purpose) We investigated the changing patterns of urogenital cancer deaths during the past 22 years in Japan.

(Methods) We analyzed patients that died from cancer of the prostate, bladder and kidney between 1973-1994. Age-adjusted death rates (adjusted to the world population), standardized mortality ratios (SMR) according to each prefectures and age-specific death rates for each types of cancer were calculated and changes in these patterns were analyzed.

(Results) Age-adjusted death rates for cancer of the prostate increased from 2.29 in 1973 to 4.36 in 1994, a 1.9-fold increase. Death rates for cancer of the bladder were stable in males and declined in females. Death rates for cancer of the kidney (15 years or older) increased from 1.45 in 1973 to 2.72 in 1994, a 1.9-fold increase in males, and tended to increase in females as well. In the SMR analysis by prefecture, distribution in 1973-84 (former period) and that in 1985-94 (later period) were similar, and characteristic features were observed for each type of cancer. Agespecific death rates for cancer of the prostate and bladder rose by an index power of age, but that for cancer of the kidney reached a plateau or decreased after an index power increase to a certain age. The rate of increase in age-specific deah rates (later period/former period) rose according to age, especially 70 years or older, in cacner of the prostate and kidney in both males and females. However, age-specific death rates in the later period from cancer of the bladder was higher only in patients 85 years or older, but was lower in other age groups.

(Conclusions) Death rates for cancer of the prostate and kidney (15 years or older) tended to increase, while that of the bladder remained stable or decreased. It is expected that detection and treatment of these disease can be improved by utilizing these epidemiologic information.

Key words: urogenital cancer, epidemiology

要旨：(目的）最近22年間の日本における尿路性器癌死亡の特徵の変遷に関して検討した。

(対象と方法) 1973-94年の間に前立腺，膀胱，腎の悪性腫瘍での死亡例を対象とした。これより，各 癌の年度別年齢調整死亡率 (世界人口にて年齢調整)，各県別標準化死亡比 (SMR)，年齢別死亡率を算 出し，それぞれの変遷に関して検討した。

(結果) 年齢調整死亡率は，前立腺では1973年に2.29であったものが1994年には4.36と約1.9倍に増加 していた，膀胱は男は横ばい，女は漸滅傾向，腎（15歳以上）は男では1973年には1.45であったものが 1994年には2.72 と約1.9倍の増加，女でも漸増傾向であった。各県別 SMR では，1973-84年（前期）と 
1985-94年(後期)の分布は似ており，それぞれの癌に特徵的な分布の偏りがみられた。年齡別死亡率は, 前立腺, 膀胱では年齢が高くなるにつれて指数関数的に増加したが，腎では増加した後に一定の年齢に なると横ばいになった，前期と後期の比較では，前立腺，腎の男女では，特に70歳以上で年齢が高くな るほど前期に対する後期の死亡率の伸び率が高かった．膀胱では，男女とも 85歳以上では後期の死亡率 の方が高かったが，それ以外のほとんどの年齢層では後期の死亡率の方が低かった.

（結論）前立腺, 腎（15歳以上）の悪性腫瘍の死亡率は増加, 膀胱は横ばい〜隇少傾向であった。こ の様な疫学情報を活用し, 効率的に各疾患の発見, 治療をすることが望まれる。

キーワード : 尿路性器癌, 疫学

\section{緒 言}

悪性新生物は，わが国では1981年以来死亡原因の第 一位になっている ${ }^{1)}$. 尿路性器癌に関しては, その死亡 率は欧米では比較的高率であるが，わが国ではいまだ に低( ${ }^{2)}$. しかし, 前立腺癌, 腎癌の死亡率は増加傾向 にあり, 徐々に欧米の水準に近づきつつある21. 世界に おけるのと同様に，日本国内においても尿路性器癌死 亡の分布には特徵がある ${ }^{3)}$. 今回, われわれは最近 22 年 間における日本の尿路性器癌の年齢調整死亡率, 各県 別標準化死亡比 (Standardized mortality ratio, $\mathrm{SMR})$, 年齢別死亡率を調查し,その変遷に関して検討 した.

\section{対象と方法}

対象は，1973～94年の間に尿路性器 (前立腺, 膀胱, 腎）の悪性腫瘍で死亡したものである。デー夕は，厚 生省大臣官房統計情報部より得た各癌の年齢別死亡 数，各県別死亡数をもとにした。これより，1973〜94 年の間の各癌の年度別年齢調整死亡率，各県別標準化 死亡比 (SMR，日本全体を 100 としたときの值)，年齢 別死亡率を求めて, それぞれの変遷に関して検討した。 死亡率は/ 10 万人/年であらわし, 年度別年齢調整死亡
率は世界人口出を基準として年齢調整を行った。また， 15歳未満の腎の悪性腫瘍による死亡はほとんどがウイ ルムス腫湯と考えられるため ${ }^{5)}$ ，年度別年齢調整死亡 率は対象を15歳以上のもののみとした．各県別標準化 死亡比 (SMR) は，それぞれの県における各癌の実際 の死亡数を期待死亡数（全体の年齢別死亡率をそれぞ れの県の人口分布にあてはめて算出）で割ったものに 100をかけたもので, 例えば SMR が130ということは, 日本の平均より $30 \%$ 死亡率が高いことを示す．前期の SMR は1980年の日本の人口分布とその期間の年齢別 死亡数を，後期の SMR は1990年の日本の人口分布と その期間の年齢別死亡数を基準としてそれぞれ算出し た。また，Ohno ら ${ }^{6)}$ の方法にしたがい，地域集積性の 検定を行い，さらに前期と後期におけるSMR の相関 係数も算出した.

\section{結 果}

1）年度別年齢調整死亡率

図 1 が，それぞれ男女の各癌の年度別年齢調整死亡 率を対数グラフ上に示したものである．前立腺では増 加傾向が著しく，1973年には2.29であったものが1994 年には 4.36 となり,この 22 年間で約 1.9 倍に増加してい

図 1 各癌の年度別年歯調整死亡率（世界人口にて年歯調整，対数目盛）

$\mathrm{a}$ :男, b：女

$1-\mathrm{a}$

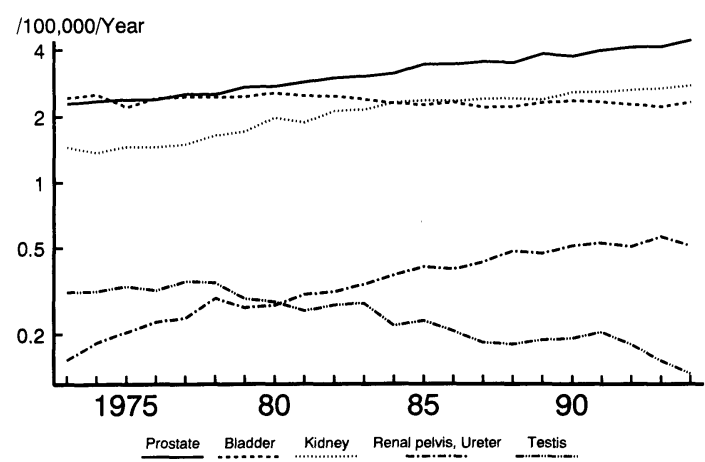

$1-\mathrm{b}$

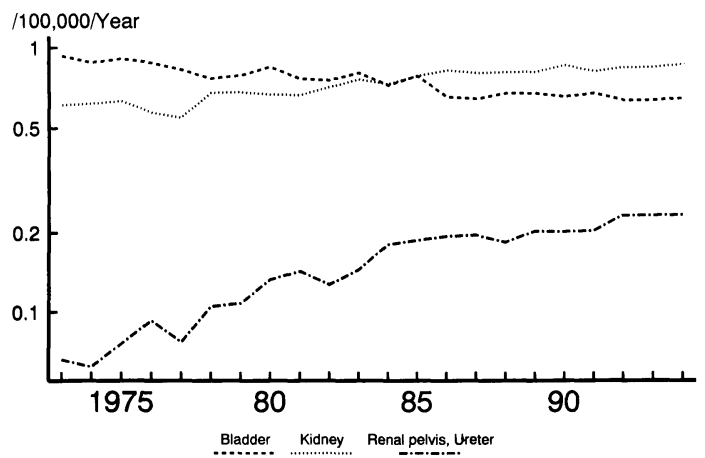


図 2 前期と後期における各癌の標準化死亡比（SMR）

—-SMR 有意高率 $(\mathrm{p}<0.05)$ の都道府県

网-SMR 有意性なしの都道府県

$\square$-SMR 有意低率（p<0.05）の都道府県

2-a

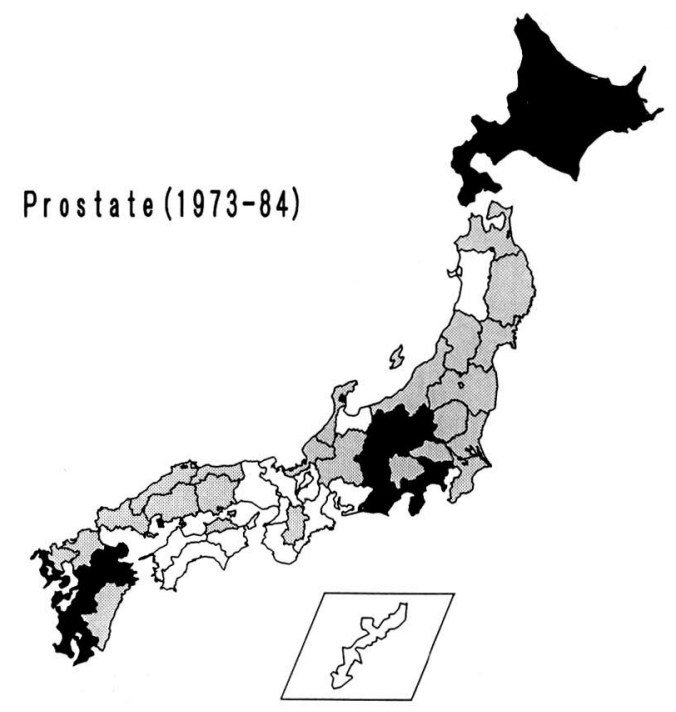

2-b

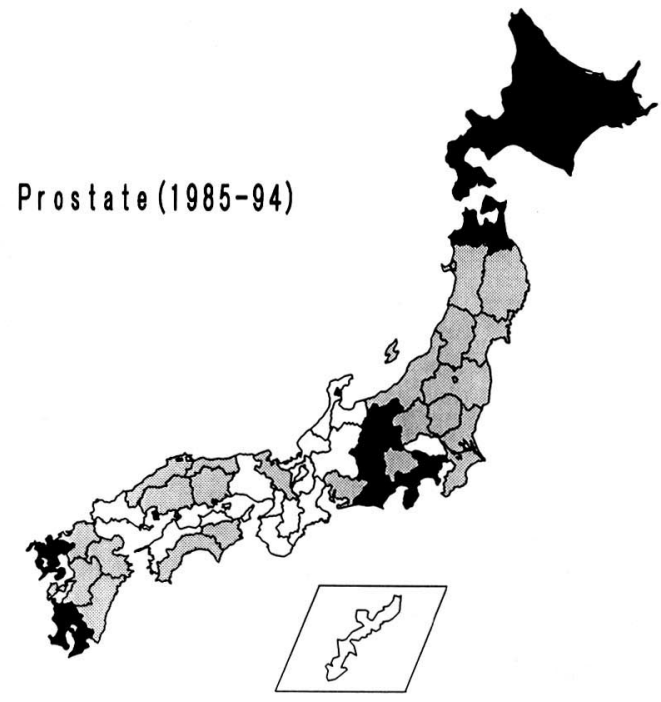

た.膀胱では男はほぼ横ばい,女は淖減傾向であった。 腎（15歳以上）では男では1973年には1.45であったも のが1994年には2.72 と約1.9倍の増加, 女でも漸増傾向 であった。

2) 各県別標準化死亡比 (SMR)

威 2 は, 各癌の各県別 SMR を1973 84年(前期)と $2-\mathrm{c}$

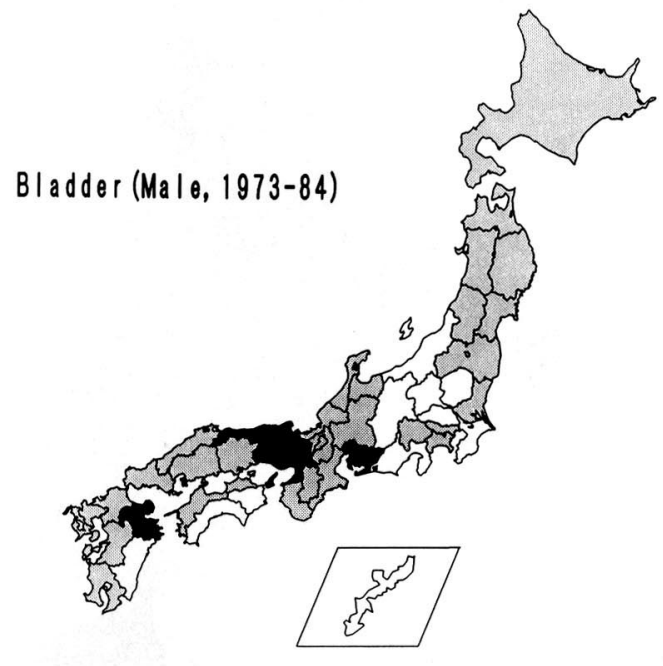

$2-d$

Bladder (Male, 1985-94)

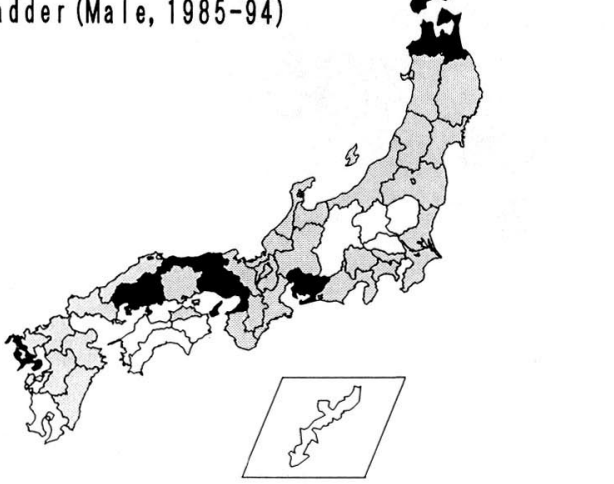

1985～94年（後期）に分けて示したものである. 前立 腺は, 日本列島の南北端と関東, 中部の東側に SMRの 高い地域が多く, 中部の西側, 近畿から四国にかけて 低い地域が多かった，膀胱の男では，西日本，特に近 畿の西側から中国に高い地域が多く, 関東, 中部の東 側, 四国に低い地域が多かった，膀胱癌の女では，高 い地域は散在しているが特に九州に多く，関東から中 部の東側に低い地域が多かった. 腎では, 男女とも高 
$2-\mathrm{e}$

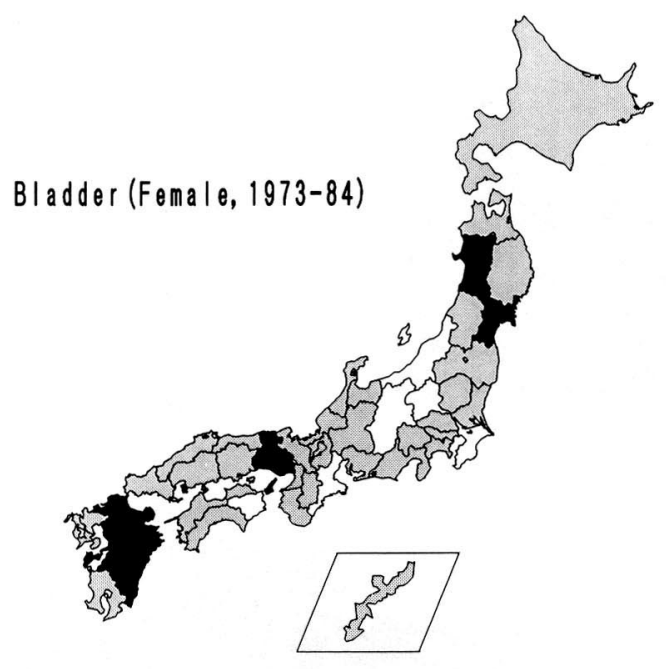

$2-\mathrm{f}$

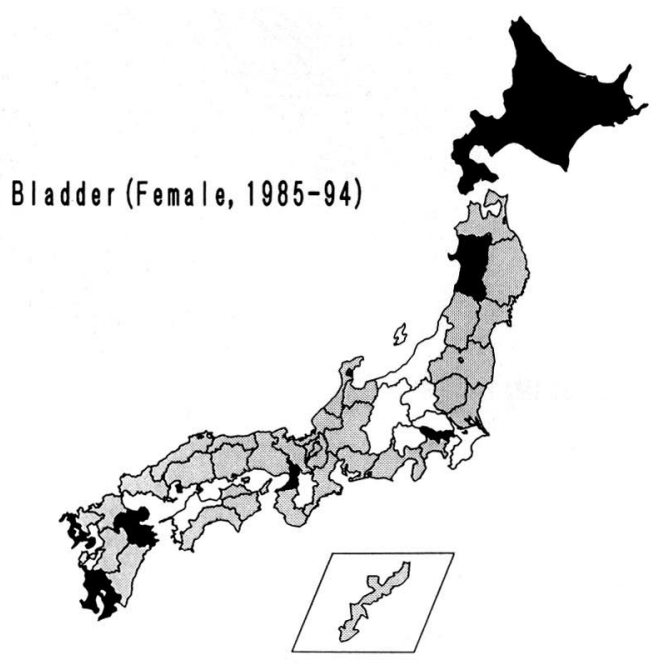

い地域は東日本, 特に東北以北と東京, 神奈川に散在 し, 関東以西では低い地域が多かった. Ohno ら ${ }^{6} の$ 方 法による地域集積の検討では, SMR 有意高率の都道 府県が有意に $(\mathrm{p}<0.05)$ 集積していたのは, 膀胱 (女) の前期のみであった。また, SMR 有意低率の都道府県 が有意に（ $\mathrm{p}<0.05 ）$ 集積していたのは，前立腺の前・ 後期, 膀胱 (男) の前 - 後期, 膀胱 (女) の後期, 腎 （女）の後期であった. 全体として有意の $(\mathrm{p}<0.05)$ 地域集積性を示したのは, 前立腺の後期のみであった。 前期と後期の SMR の相関係数は, 前立腺 0.66 , 膀胱 (男) 0.60 , 膀腅 (女) 0.58 , 腎 (男) 0.71 , 腎 (女) 0.70 といずれも高く $(\mathrm{p}<0.01)$, 各癌とも前期と後期 $2-g$

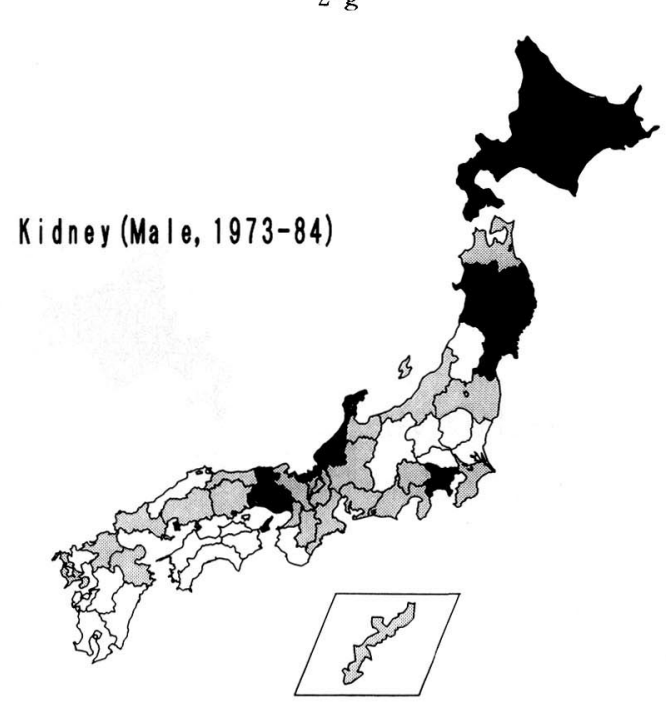

2-h

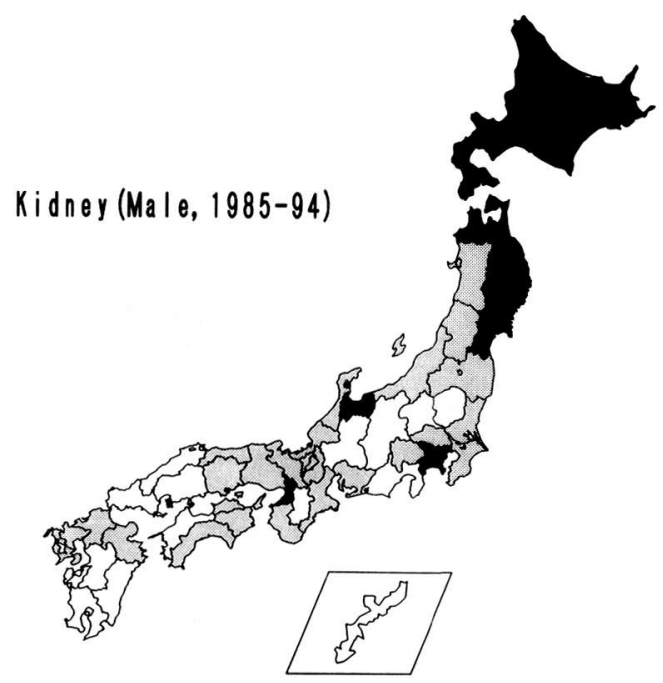

の分布は非常に似ており，分布の偏りが偶然起きたの ではないことが示唆された。

3）年秢別死亡率

図 3 が, 各癌の年齢別死亡率を前期と後期にわけて 示したものである. 前立腺, 膀胱では年齢が高くなる につれて死亡率は指数関数的に増加したが，腎では増 加した後に一定の年齢になると横ばいになった. 表 1 は，前期に対する後期の年䍅別死亡率の比を示したも のである. 前立腺, 腎の男女では, 特に70歳以上で年 齢が高くなるほど前期に対する後期の死亡率の伸び率 
$2-\mathrm{i}$

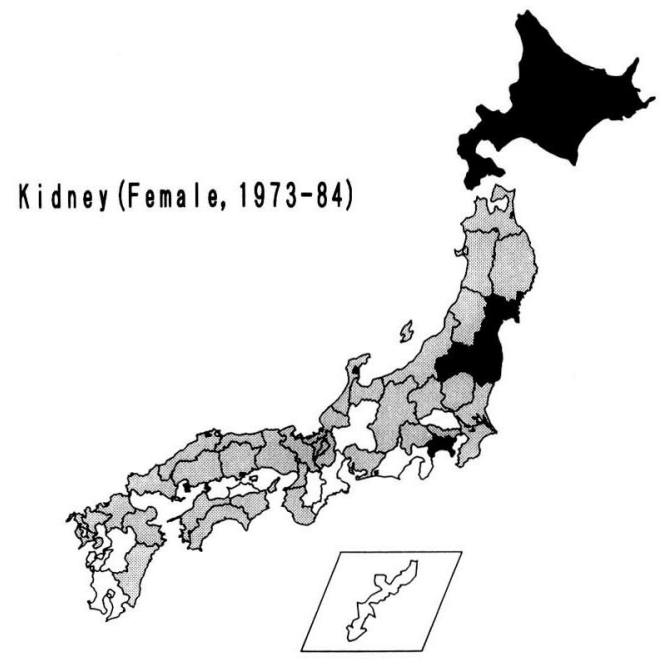

$2-\mathrm{j}$

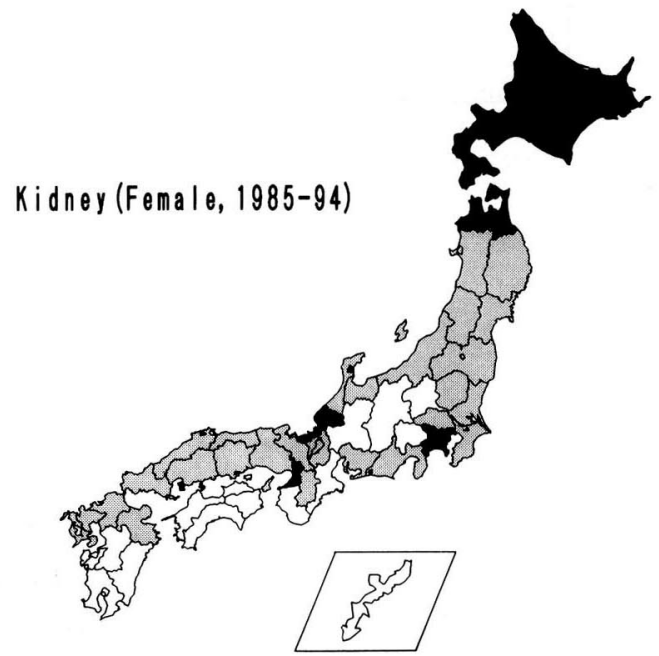

が高かった．膀肶では，男女とも85歳以上では後期の 死亡率の方が高かったが，それ以外のほとんどの年齢 層では後期の死亡率の方が低かった。

\section{考察}

尿路性器癌の頻度は, 日本では増えつつあるものの いまだに少ないが, 欧米ではたいへん多い22. 特に前立 腺癌はアメリカの1996年における発生は317,100人,死 亡は 41,400 人であると予測され, 男性癌発生の 1 位, 死亡の 2 位を占めている77. しかし，日本でもその死亡 率は增加しつつあり，大野ら鼻によると1947年には 0.16であったものが1987年には 3.55 と約 22.2 倍の，そ してわれわれの結果より1994年には4.36と約27.3倍の 増加を示している．アメリカに移民した日本人の前立 腺癌の発生率が高い量ことより, 食生活が癌発生の大 きな役割を占めていると考えられている．世界でもほ とんどの国で死亡率は増加傾向にある ${ }^{2)}$. 膀胱癌の発 生率は,アメリカの National cancer survey data で は，男は白人，黒人とも増加傾向，女はともにやや減 少傾向である ${ }^{10)}$. 死亡率は, 増加している国と隇少して いる国がある2．日本では，発生率は男では増加，女で

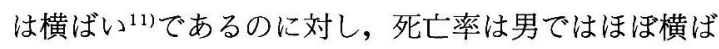
い, 女では減少傾向である. 契煙が膀腅癌の強い危険 因子とされている ${ }^{12) \sim 15)}$. 喫煙率は男に高く，また膀胱 癌の死亡率も男に高い。しかし，哭煙率は男では減少 傾向で女では横ばい'16)であり, 膀胱癌の発生率は男で 増加, 女で横ばいであることを考えると, 死亡率の変 化は喫煙率低下による影響ではないのかもしれない。 Catalona ${ }^{17)}$ は, アメリカでの同様の現象は, 早期診断 と治療技術の向上のためであるとのべている.腎癌は, アメリカのコネチカットの癌登録資料によるとその発 生率は男女とも着実に増加しており, 今後もさらに増 えると予測されている ${ }^{18)}$. 現在のところ, 喫煙や肥満が 危険因子とする報告 ${ }^{19)}$ 21) が多く, 食事, コーヒーやア ルコールの攝取, ある種の疾患の既往等との関係を示 唆する報告もみられる22)。

各県別の死亡率に関しては, 前期と後期でそれぞれ の癌で非常に似た分布をしており，偏りがある期間だ け偶然に起こったのではないことを示唆する結果で

表 1 年齢別死亡率の前期に対する後期の比率（1985-94/1973-84）

\begin{tabular}{l|c|c|c|c|c|c|c|c|c|c|c|c}
\hline \multicolumn{1}{c|}{ Age } & $30-$ & $35-$ & $40-$ & $45-$ & $50-$ & $55-$ & $60-$ & $65-$ & $70-$ & $75-$ & $80-$ & $85-$ \\
\hline Male & & & & & & & & & & & & \\
$\quad$ Prostate & 1.2 & 0.8 & 0.7 & 1.2 & 1.3 & 1.3 & 1.2 & 1.3 & 1.4 & 1.4 & 1.5 & 1.9 \\
Bladder & 1.2 & 0.8 & 0.8 & 0.8 & 0.8 & 0.8 & 0.8 & 0.9 & 0.9 & 1.0 & 1.1 & 1.4 \\
Kidney & 2.3 & 1.3 & 1.2 & 1.1 & 1.3 & 1.3 & 1.2 & 1.4 & 1.6 & 1.8 & 2.1 & 2.8 \\
Female & & & & & & & & & & & & \\
Bladder & 1.4 & 0.7 & 0.8 & 0.8 & 0.7 & 0.7 & 0.6 & 0.7 & 0.7 & 0.9 & 1.0 & 1.4 \\
Kidney & 1.2 & 1.2 & 1.0 & 1.0 & 1.1 & 1.1 & 1.1 & 1.2 & 1.3 & 1.6 & 2.3 & 2.4 \\
\hline
\end{tabular}


図 3 各癌の年歯別死亡率

$\mathrm{a}$ : 前立腺, $\mathrm{b}$ : 膀胱, $\mathrm{c}$ ：腎

3-a

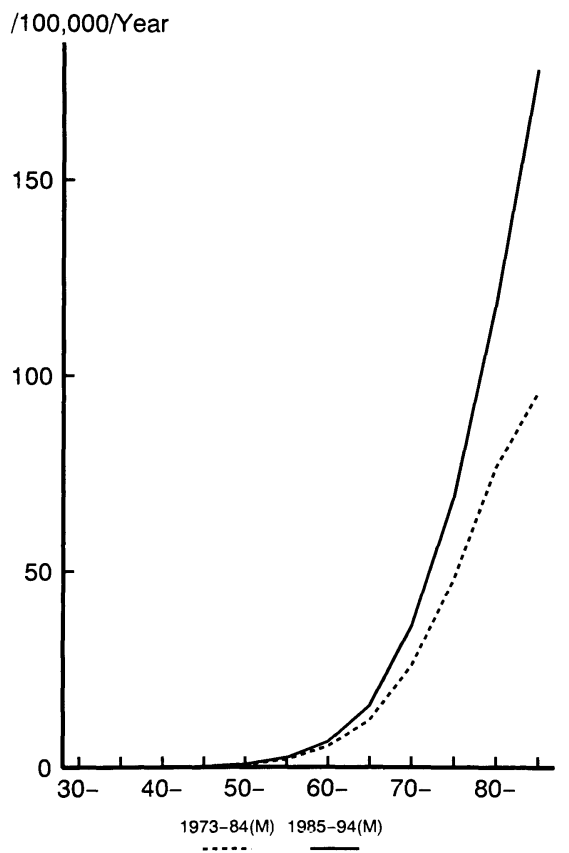

3-b

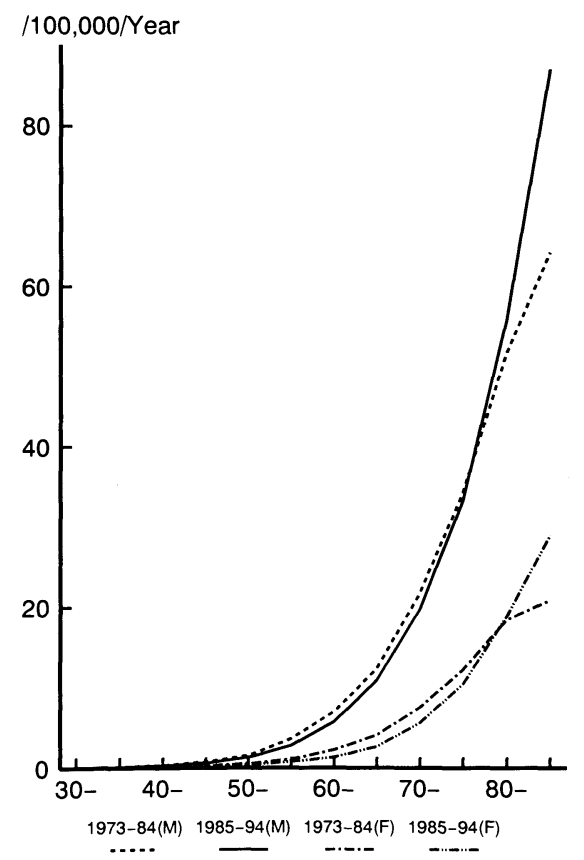

$3-\mathrm{c}$

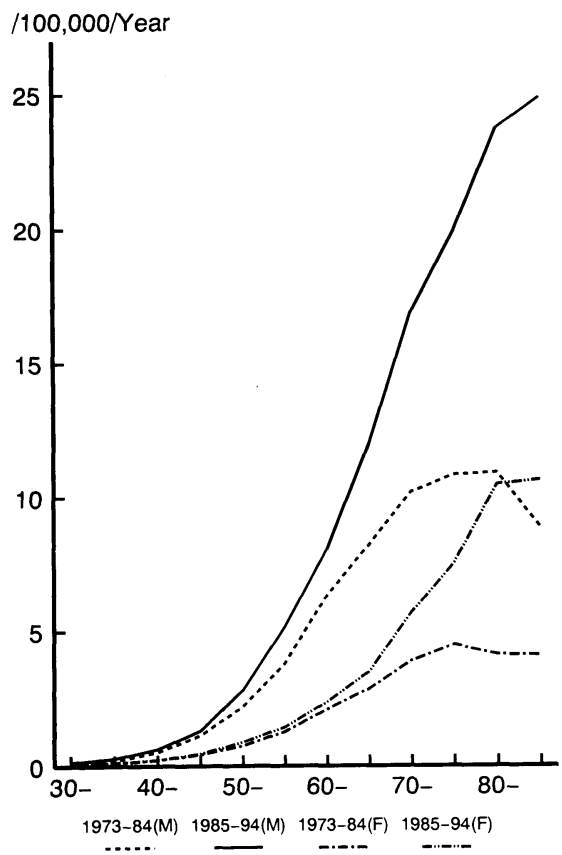

あった，胃癌，食道癌，肝癌のように，日本国内の特 徵的な分布の原因が比較的明らかになってきている ${ }^{23)}$ ものもあるが，尿路性器癌に関しては今までのところ はっきりした原因は示されていない.しかし, 中田ら ${ }^{24)}$ は前立腺癌の各県別標準化死亡比と食用油や豚肉とい う脂肪に富む食品の消費との間に正の相関をみとめ, 食事が前立腺癌の分布の偏りの一因になっている可能 性を示唆している. 喫煙は膀胱癌の最大の危険因 子(2) 15)である. Nakata ${ }^{25)}$ は，世界における検討で はヨーロッパという限られた地域においては喫煙率と 膀胱癌死亡率との間に正の相関があるが, 全く人種の 異なる地域にまで範囲を広げると相関はなくなり，世 界の膀胱癌死亡率の差は喫煙率よりも人種の影響が大 きいとのべている，はたして，各県別男女別の喫煙率 と膀胱癌死亡率との間に相関があるかどうかが非常に 興味深いが, 残念ながら各県別喫煙率のデー夕は得る ことができず，またこれを検討した報告も見あたらな い. 䇾輪 ${ }^{26)}$ は腎細胞癌の死亡率は県別による検討では 北日本に偏っている印象を受けるが，市町村別による 検討では都市部ほど, 脂肪, 蛋白捸取が多いほど高い 傾向があり, 食事が分布の偏りの一因である可能性を 
示唆している.

年歯別死亡率では，前立腺，膀胱ではともに年齢に ともなって指数関数的に増加しており，ともに年齢依 存性の癌であることがよくわかる. 死亡率の増加率も 高齢者，特に70歳以上で年歯とともに高くなった。高 齢者は，他の合併症を持っていたり，家庭の事情等の ために充分な治療を行えなかったり, 過度の治療によ りかえって生存期間を縮めたりすることも有り得る. 今後は高齢の患者がますます増えることになる，われ われ医療者側は患者一人一人の異なった条件の中で, その患者にとって QOL も考慮に入れた最適の治療の 選択を迫られる機会がますます増えていくであろう。

癌による死亡は年々増加しつつあり, 富永ら ${ }^{27)} に よ$ ると2000年における全国癌死亡数は男女合計で 310,000 人と推計され, これは1986年の実測死亡数 (191,654人) の1.62倍であるとのべている. 尿路性器 癌に関しても同様で, 2000年における推計死亡数と 1986年の実測死亡数の比は, 前立腺癌は 2.36 , 膀胱癌 は男女とも1.68である.この様な疫学情報を活用して, 特に一般大衆への啓蒙や診断機会の増加をはかり, 今 後さらに効率的な各疾患の発見に努めることが重要で ある。

\section{結語}

1973～94年の間の前立腺，膀胱，腎の悪性腫瘍の年 度別年齢調整死亡率, 各県別標準化死亡比 (SMR), 年 齢別死亡率を求めて, 22 年間の変遷に関して検討した. 死亡率は/ 10 万人/年であらわし, 年度別年齢調整死亡 率は世界人口を基準として年齢調整を行った。

1）年度別年齢調整死亡率は, 前立腺では増加傾向が 著しく，この22年間で約1.9倍に増加した.膀胱では男 はほぼ横ばい，女は漸減傾向であった。腎(15歳以上) では, 男は前立腺と同様に 22 年間で約 1.9 倍の増加, 女 でも漸増傾向であった。

2) 各県別標準化死亡比 (SMR) は，1973～84年 (前 期）と1985～94年（後期）に分けて検討すると，各癌 とも前期と後期の分布は非常に似ており，それぞれの 癌に特徴的な分布の偏りがみられた。

3）年齢別死亡率は, 前立腺, 膀胱では年歯が高くな るにつれて指数関数的に増加したが，腎では増加した 後に一定の年齢になると横ばいになった。前期と後期 の比較では, 前立腺, 腎の男女では, 特に70歳以上で 年齢が高くなるほど前期に対する後期の死亡率の伸び 率が高かった. 膀胱では, 男女とも85歳以上では後期 の死亡率が高かったが, それ以外のほとんどの年齢層
では後期の死亡率の方が低かった。

\section{文献}

1）厚生統計協会 : 国民衛生の動向. 厚生統計協会編, 42, p416,厚生統計協会, 東京, 1995.

2) Kuroishi, T., Hayakawa, N., Kurihara, M. and Aoki, K. : Cancer mortality in 33 countries of the world (1953-1987). In Cancer Mortality and Morbidity Statistics - Japan and the World1994, Japan Scientific Societies Press, Tokyo, 1994.

3) Nakata, S. and Yamanaka, H. : Epidemiology of urological cancer deaths in Japan. Int. J. Urol., 1, 114-120, 1994.

4) Smith, P.G.: Comparison between registries: Age-standardized rates. In Cancer Incidence in Five Continents, Vol. VI, p868, International Agency for Research on Cancer, Lyon, 1992.

5）大野良之, 青木国雄, 黒石哲生, 富永祐民：日本人 の尿路性器癌の疫学. 臨泌, 38, 555-569, 1984.

6) Ohno, Y., Aoki, K. and Aoki, N.: A test of significance for geographic clusters of disease. Int. J. Epidemiol., 8, 273-281, 1979.

7) Parker, S.L., Tong, T., Bolden, S. and Wingo, P. A. : Cancer statistics, 1996. CA Cancer J. Clin., 46, 5-27, 1996.

8）大野良之, 久保奈佳子, 黒石哲生：前立腺癌の疫学 特性一日本と世界。図説臨床 [癌] シリーズ No. 32 , 癌とホルモン, p58一-67,メジカルビュー社, 東 京, 1990.

9) Shimizu, H., Ross, R.K., Bernstein, L., Yatani, R., Henderson, B.E. and Mack, T.M. : Cancers of the prostate and breast among Japanese and white immigrants in Los Angels County. Br. J. Cancer, 63, 963-966, 1991.

10) Morrison, A.S.: Advances in the etiology of urothelial cancer. Urol. Clin. North Am., 11, $557-566,1984$.

11）熊本伊三郎，村上良介，花井 彩, 祖父江友孝, 大 島 明, 田中英夫, 日山興彦, 味木和喜子, 津熊秀 明：大阪府の癌の罹患と死亡1963-1989, 大阪府 における癌の罹患と死亡.（財）大阪成人病予防協 会, 大阪, 1993.

12) Sorahan, T., Lancashire, R.J. and Sole, G. : Urothelial cancer and cigarette smoking : Findings from a regional case-controlled study. Brit. J. Urol., 74, 753-756, 1994.

13) Cordier, S., Clavel, J., Limasset, J.C., BocconGibod, L., Moual, N.L., Mandereau, L. and Hemon, D.: Occupational risks of bladder cancer in France: A multicentre case-control study. Int. J. Epidemiol., 22, 403-411, 1993. 
14) Morrison, A.S., Buring, J.E., Verhoek, W.G., Aoki, K., Leck, I., Ohno, Y. and Obata, K. : An international study of smoking and bladder cancer. J. Urol., 131, 650-654, 1984.

15) Lopez-Abente, G., Gonzalez, C.A., Errezola, M., Escolar, A., Isarzugaza, I., Nebot, M. and Riboli, E.: Tobacco smoke inhalation patterns, tobacco type, and bladder cancer in Spain. Am. J. Epidemiol., 134, 830-839, 1991.

16）厚生省：喫煙と健康. 喫煙と健康問題に関する報 告書, 第 2 版, 厚生省編, p269, (財) 健康·体力 づくり事業財団，東京，1993.

17) Catalona, W.J.: Urothelial tumors of the urinary tract. In Campbell's Urology. 6th ed., p1095, Saunders Co., Philadelphia, 1992.

18) Katz, D.L., Zheng, T., Holford, T.R. and Flannery, J.: Time trends in the incidence of renal cell carcinoma : Analysis of Connecticut tumor registry data, 1935-1989. Int. J. Cancer, 58, 57 $-63,1994$.

19) Yu, M.C., Mack, T.M., Hanisch, R., Cicioni, C. and Henderson, B.E. : Cigarette smoking, obesity, diuretic use, and coffee consumption as risk factors for renal cell carcinoma. J. Natl. Cancer Inst., 77, 351-356, 1986.
20) Goodman, M.T., Morgenstern, H. and Wynder, E.L. : A case-control study of factors affecting the development of renal cell cancer. Am. J. Epidemiol., 124, 926-941, 1986.

21) Wynder, E.L., Mabuchi, K. and Whitmore, W. F.: Epidemiology of adenocarcinoma of the kidney. J. Natl. Cancer Inst., 53, 1619-1634, 1974.

22）大野良之, 久保奈佳子, 黒石哲生：腎腫湯の疫学像 と関連要因. 病理と臨床, 8, 720-725, 1990.

23）黒石哲生, 広瀬かおる, 富永祐民：日本人がんの地 理的分布. 日本臨床，43，2207-2226，1985.

24）中田誠司, 今井強一, 山中英壽, 矢嶋久徳: 日本お よび世界における前立腺癌死亡と食捸取様式の相 関分析. 癌の臨床, 40,831-836, 1994.

25) Nakata, S., Sato, J. and Yamanaka, H.: Correlation analysis between bladder cancer and cigarette smoking in various countries. Tohoku J. Exp. Med., 178, 169-176, 1996.

26）箕輪眞澄：腎細胞癌の市町村別分布とその関連要 因. 泌尿紀要, 38，237-253，1992.

27）富永祐民, 広瀬かおる, 黒石哲生：日本におけるが ん死亡の将来予測. 癌と化学療法, 16, 101-111, 1989.

（1995年12月 4 日受付，1996年 8 月13日受理） 